Jurnal Basicedu Volume 4 Nomor 2 April 2020 Hal. 337-343

JURNAL BASICEDU

Research \& Learning in Elementary Education

https://jbasic.org/index.php/basicedu

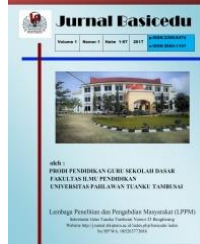

\title{
PEMANFAATAN MEDIA PEMBELAJARAN PADA PEMBELAJARAN TEMATIK TERPADU DI SEKOLAH DASAR
}

\author{
Rejeki1 , M.Fachri Adnan² ${ }^{2}$ Pariang Sonang Siregar ${ }^{3}$ \\ STKIP Rokania, Riau, Indonesia ${ }^{1,2,3}$ \\ E-mail: rejekijekimuria87@gmail.com ${ }^{1}$ E-mail:fachri.adnan@gmail.com ${ }^{2,}$ E-mail: $\underline{\text { sonang86@gmail.com }}{ }^{3}$
}

\begin{abstract}
Abstrak
Penelitian ini bertujuan untuk mengetahui pemanfaatan media pembelajaran dalam pembelajaran tematik terpadu di Sekolah Dasar kelas III tahun ajaran 2019/2020. Jenis penelitian ini adalah penelitian kualitatif deskriptif. Lokasi penelitian adalah Sekolah Dasar Negeri 009 Kepenuhan Kabupaten Rokan Hulu Riau. Subyek Penelitian adaah Kepala Sekolah, Wakil Kepala Sekolah, dan Guru kelas III A dan B Sekolah Dasar Negeri 009 Kepenuhan.Hasil penelitian Pemanfaatan media pembelajaran pada pembelajaran Tematik Terpadu pada kelas III SD Negeri 009 Kepenuhan bila dirancang dengan baik merupakan media pembelajaran yang efektif, dapat memudahkan dan meningkatkan kualitas pembelajaran, meningkatkan motivasi belajar siswa, mendukung pembelajaran individual sesuai kemampuan siswa, dan dapat digunakan sebagai penyampaian pesan langsung. Kegunaan dan peran media pembelajaran memperjelas penyajian pesan agar tidak terlalu bersifat verbalistis, mengatasi keterbatasan ruang, waktu dan daya indera. Faktor pendukung $\mathrm{m}$ media pembelajaran sudah banyak di sediakan oleh sekolah dan siswa. Dengan adanya media pembelajaran siswa sangat tertarik untuk belajar, dengan kehadiran media membuat siswa lebih termotivasi untuk belajar karena siswa tidak menerawang dalam belajar.
\end{abstract}

Kata Kunci: Media Pembelajaran, Pembelajaran Tematik Terpadu

\begin{abstract}
This study aims to determine the use of instructional media in integrated thematic learning in elementary schools in class III of the 2019/2020 school year. The type of this research is descriptive qualitative. The location of the study was 009 National Elementary School. Research Subjects are Principal, Vice Principal, and Teachers of Class III A and B of State Elementary School 009 Fullness. Research results Utilization of instructional media in Integrated Thematic learning in class III Elementary School 009 Compliance when well designed is an effective learning medium, can facilitate and improve the quality of learning, increase student's motivation, support individual learning according to students' abilities, and can be used as direct delivery of messages. The usefulness and role of instructional media clarifies the presentation of messages so as not $t$ verbalistic, to overcome the limitations of space, time and senses. Supporting factors in learning media have been provided by many schools and students. With the learning media students are very interested in learning, with the presence of media makes students more motivated to learn because students are not dreamy in learning.
\end{abstract}

Keywords: Learning Media, Thematic Integrated Learning

@ Jurnal Basicedu 2020

$\triangle$ Corresponding author :

Address :-

ISSN 2580-3735 (Media Cetak)

Email :-

ISSN 2580-1147 (Media Online)

Phone :- 
338 Pemanfaatan media pembelajaran pada pembelajaran tematik terpadu di sekolah dasar-Rejeki, M. Fachri Adnan, Pariang Sonang Siregar

\section{PENDAHULUAN}

Guru sebagai seorang pendidik menciptakan situasi agar siswa mengalami proses pembelajaran. Belajar adalah proses perubahan tingkah laku yang ditimbulkan akibat adanya rangsangan dari luar. Belajar melibatkan berbagai unsur yang ada di dalamnya, berupa kondisi fisik dan psikis orang yang belajar. Kedua kondisi tersebut akan sangat berpengaruh terhadap hasil belajar, antara lain suasana lingkungan saat belajar, tersedianya media pembelajaran dan sebagainya. Oleh karena itu, unsur-unsur tersebut perlu mendapatkan perhatian guna menunjang tercapainya tujuan belajar sesuai dengan yang diharapkan.

Untuk menunjang keberhasilan belajar diperlukan media pembelajaran. Sebab, dengan tersedianya media pembelajaran siswa dimungkinkan akan lebih berpikir secara konkret dan hal ini berarti dapat mengurangi verbalisme pada diri siswa. Hal demikian mengakibatkan siswa termasuk guru dapat memilih atau menggunakan media pembelajaran dalam proses belajar. Dalam proses pembelajaran kehadiran media mempunyai arti yang cukup penting. Karena dalam kegiatan tersebut ketidakjelasan bahan yang disampaikan dapat dibantu dengan menghadirkan media sebagai perantara. Menurut Susilana (2009:6) kerumitan bahan yang akan disampaikan kepada siswa dapat disederhanakan dengan bantuan media. Media dapat mewakili apa yang kurang mampu guru ucapkan melalui kata-kata atau kalimat tertentu

Agar proses belajar mengajar dengan media pembelajaran dapat berhasil dengan baik, siswa sebaiknya diajak untuk memanfaatkan semua alat indranya. Guru berupaya memberikan rangsangan yang dapat di peroses dengan berbagai indera. Menurut Arsyad (2016:11) Semakin banyak alat indera yang digunakan untuk menerima dan mengolah informasi semakin besar kemungkinan informasi tersebut dimengerti dan di pertahankan dalam ingatan. Dengan adanya media pembelajaran siswa diharapkan akan dapat menerima dan menyerap dengan mudah dan baik pesan-pesan dalam materi yang di sajikan. Dalam menjalankan tugasnya sehari-hari sering kali guru harus berhadapan dengan siswa-siswa yang prestasi akademisnya tidak sesuai dengan harapan guru, banyak faktor yang mepengaruhi hasil belajar siswa, salah satunya adalah media pembelajaran.

Berdasarkan permasalahan diatas maka penulis tertarik untuk melakukan penelitian dengan judul “ Pemanfaatan Media Pembelajaran Pada Pembelajaran Tematik Terpadu Kelas III SD Negeri 009 Kepenuhan Kabupaten Rokan Hulu Riau”

\section{METODE}

Jenis penelitian ini adalah penelitian kualitatif. Penelitian kualitatif adalah penelitian yang dimaksudkan untuk memahami fenomena tentang apa yang dialami oleh subjek penelitian menghasilkan data deskriptif berupa kata-kata yang tertulis atau lisan dari orang-orang dan perilaku yang diamati. Dengan begitu dapat dikatakan bahwa penelitian ini bersifat deskriptif kualitatif. Artinya, penulis menganalisis dan menggambarkan penelitian secara objektif dan mendetail untuk mendapatkan hasil yang akurat. Pendekatan kualitatif peneliti gunakan karena objek yang diteliti berlangsung dalam latar wajar dan bertujuan untuk mengetahui, memahami, dan menghayati dengan seksama dan lebih mendalam tentang bagaimana pemanfaatan media pembelajaran dalam pembelajaran tematik terpadu pada kelas III Sekolah Dasar

Data dalam penelitian ini adalah data primer dan data sekunder. Data primer adalah data yang 
339 Pemanfaatan media pembelajaran pada pembelajaran tematik terpadu di sekolah dasar-Rejeki, M. Fachri Adnan, Pariang Sonang Siregar

dikumpulkan secara langsung oleh peneliti itu sendiri, yaitu data hasil observasi dan wawancara dalam pelaksanaan Pemanfaatan Media Pembelajaran Pada Pembelajaran Tematik Terpadu Kelas III SD Negeri 009 Kepenuhan Kabupaten Rokan Hulu Riau. Data primer diperoleh dari Kepala Sekolah, Wakil Kepala Sekolah, Guru kelas III A dan guru kelas III B. Sedangkan data sekunder adalah data yang dikumpulkan oleh peneliti lainnya.

Pemahaman mengenai berbagai macam sumber data merupakan bagian yang penting. Data tidak akan bisa diperoleh tanpa adanya sumber data. Adapun jenis sumber data menurut Sutopo (2002: 50) adalah sebagai berikut:

\section{a. Nara sumber (informan)}

Jenis sumber data yang berupa data yang berupa manusia pada umumnya dikenal sebagai responden. Istilah tersebut sangat akrab digunakan dalam penelitian kualitatif, dengan pengertian bahwa peneliti memiliki posisi yang lebih penting. Responden posisinya sekedar memberikan tanggapan (respon) pada apa yang diminta atau ditentukan penilitinya. Dalam penelitian kualitatif posisi sumber data manusia (nara sumber) sangat penting peranannya sebagai individu yang memiliki informasi. Peneliti dan nara sumber disini memiliki posisi yang sama dan nara sumber bukan memberikan sekedar tanggapan pada yang diminta peneliti, tetapi ia lebih bisa memilih arah dan selera dalam menyajikan informasi yang ia miliki. Nara sumber (informan) dalam penelitian ini adalah: kepala sekolah, wakil kepala sekolah, guru.

b. Peristiwa atau aktivitas

Data atau informasi juga dapat dikumpulkan dari peristiwa, aktivitas, atau perilaku sebagai sumber data yang berkaitan dengan sasaran penelitiannya. Dari pengamatan pada peristiwa atau aktivitas, peneliti bisa mengetahui proses bagaimana sesuatu terjadi secara lebih pasti karena menyaksikan sendiri secara

Dalam penelitian kualitatif, data diperoleh dari berbagai sumber dengan menggunakan teknik pengumpulan data bermacam-macam (triangulasi), dan dilakukan secara terus menerus sampai datanya jenuh. Dengan pengamatan yang terus menerus tersebut mengakibatkan variasi datanya tinggi. Data yang diperoleh umumnya data kualitatif ( walaupun tidak menolak data kuantitatif), sehingga teknik analisis data yang digunakan belum ada pola yang jelas. Oleh karena itu sering mengalamikesulitan dalam melakukan analisis. Analisis data dilakukan melalui tiga tahapan Miles dan Huberman dalam Sugiono (2017: 133), aktivitas dalam analisis data kualitatif dilakukan secara interaktif dan berlangsung secara terus menerus sampai tuntas, sehingga data sudah jenuh. Aktifitas dalam analisis data yaitu: data reduction, data display dan conclusion drawing/verification.

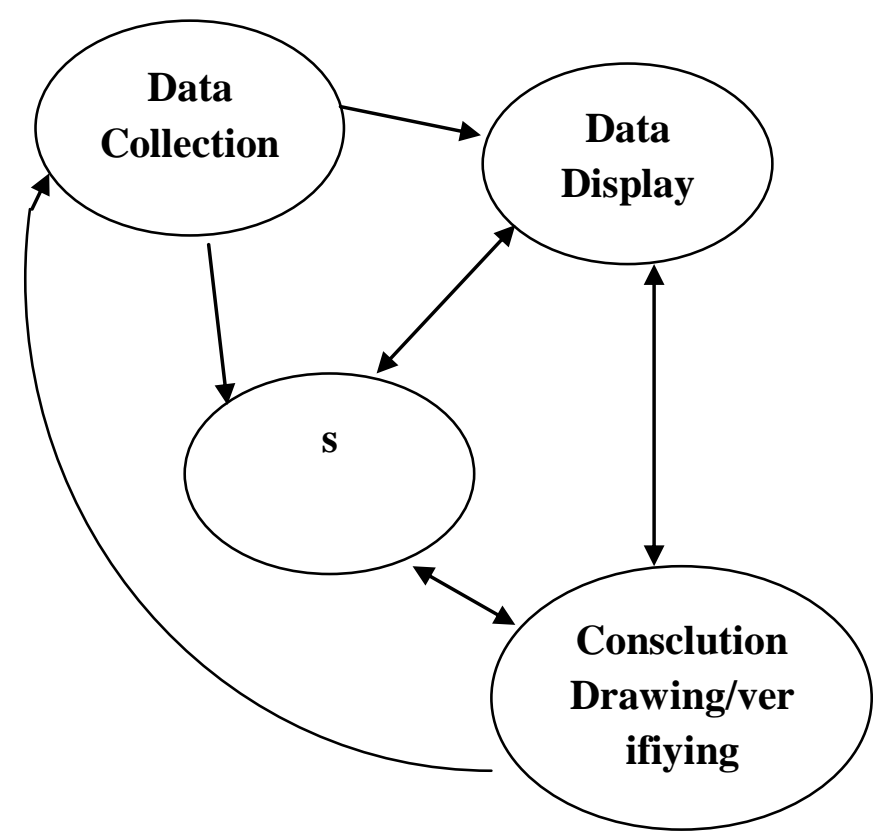

Gambar 1. Analisis data 
340 Pemanfaatan media pembelajaran pada pembelajaran tematik terpadu di sekolah dasar - Rejeki, M. Fachri Adnan, Pariang Sonang Siregar

Komponen analisis data diatas dapat dijelaskan sebagai berikut:

\section{Data collection (Pengumpulan Data)}

Dalam penelitian ini peliti mengumpulkan data. dengan cara observasi, wawancara mendalam dan dukumentasi atau gabungan ketiganya (triagulasi). Pada tahap awal peneliti melakukan penjelajahan secara umum terhadap situasi/ obyek yang akan di teliti, semua yang dilihat dan didengar direkam semua.

\section{Data Reduction (Data Reduksi)}

Data yang diperoleh dari lapangan jumlahnya cukup banyak, maka perlu dicatat secara teliti dan rinci. Untuk itu perlu segera dilakukan analisis data melalui reduksi data. Mereduksi data berarti merangkum, memilih dan memilih hal-hal yang pokok, memfokuskan pada hal-halyang penting, dicari tema dan polanya. Dengan demikian data yang telah direduksi memberikan gambaran yang jelas dan memudahkan peneliti untuk pengumpulan data pada tahap selanjutnya, dan mencarinaya bila diperlukan.

\section{Data Display (Penyajian Data)}

Setelah data direduksi, maka langkah selanjutnya mendisplaykan data. Dalam penelitian kualitatif, Data bisa dilakukan dalam bentuk uraian singkat, bagan, hubungan antar ketegori, flowchart dan sejenisnya. Yang paling sering digunakan untuk menyajikan data dalam penelitian kualitatif adalah dengan tesk yang bersifat naratif.

\section{Conclusion Drawing/Verification}

Langkah ke empat dalam analisis data kualitatif adalah penarikan kesimpulan dan Verifikasi. Kesimpulan awal yang dikemukakan bersifat sementara, dan akan berubah-ubah bila tidak ditemukan bukti-bukti yang kuat yang mendukung pada tahap pengumpulan data berikutnya. Tapi apabila kesimpulan yang dikemukakan pada tahap awal, didukung oleh bukti-bukti yang validdan konsisten saat peneliti kembali ke lapangan mengumpulkan data maka kesimpulan yang dikemukakan merupakan kesimpulan yang kredibel.

\section{HASIL DAN PEMBAHASAN}

Berdasarkan hasil penelitian pemanfaatan media pembelajaran pada pembelajaran tematik terpadu di kelas III SD negeri 009 Kepenuhan. Pemanfaatan media pembelajaran pada pembelajaran tematik terpadu di kelas III SD Negeri 009 Kepenuhan Kabupaten Rokan Hulu Riau telah dimulai sejak awal tahun ajaran 2006/2007, dimana pada mulanya media yang tersedia di sekolah berupa media gambar, alat-alat berhitung, atlas, globe. Saat ini di SD Negeri 009 Kepenuhan sudah memakai media berupa infokus dan leptop. Dengan kehadiran media dianggap membantu guru dan siswa dalam proses pembelajaran, maka pada saat ini sudah tersedia banyak media.

Pentingnya pemanfaatan media diakui Erawati, S.Pd (wawancara, tanggal 12 Oktober 2019) sebagai berikut:

Sekarang media pembelajaran tidak hanya digunakan untuk efisiensi dan efektifitas dalam pengelolaan penyelenggaraan sekolah saja. Media pembelajaran dapat digunakan untuk mempermudah menunjukkan pengetahuan, memberi daya tarik yang lengkap, menyentuh seluruh modalitas anak dengan desain media yang menarik. Penyajian bahan ajar dalam bentuk media pembelajara dapat dirancang sesuai dengan tema untuk keperluan mengajar.

Hasil wawacara dengan beberapa guru dapat diketahui bahwa dengan adanya media pembelajaran guru merasa terbantu dalam menyampaikan materi pembelajaran, salah satu keuntungan yang dirasakan oleh guru dengan digunakannya media pembelajaran dalam kegiatan 
341 Pemanfaatan media pembelajaran pada pembelajaran tematik terpadu di sekolah dasar-Rejeki, M. Fachri Adnan, Pariang Sonang Siregar

proses belajar mengajar media dapat menyajikan materi dengan efisien, selain itu siswa lebih tertarik dalam proses pembelajaran. Banyak hal yang dapat disajikan oleh guru menggunakan media dalam pembelajaran misalnya ketika guru mengajar tema lingkungan di sekitar kita dengan adanya media pembelajaran guru dapat menampilkan beberapa gambar baik yang berupa gambar diam maupun gambar bergerak, selain itu catatan-catatan penting yang harus dipahami siswa dapat dipaparkan dengan menggunakan infokus.

Bentuk pemanfaatan media dalam pembelajaran seperti dikemukakan oleh Era wati (wawancara, tanggal 12 Oktober 2019) adalah: baru sebatas untuk menyampaikan materi pelajaran. Senada dengan pernyataan tersebut $\mathrm{Hj}$. Jamilah (wawancara, tanggal 12 Oktober 2019), mengatakan: Memang pemanfaatan media dalam pembelajaran, saat ini baru dimanfaatkan oleh guru sebatas menyampaikan materi pembelajaran sedangkan untuk keperluan lainnya seperti pembelajaran interaktif kami belum mampu melakukannya.

Walaupun sebatas penggunaan untuk membantu guru dalam menyampaikan bahan ajar, hal tersebut dirasa sudah sangat membantu guru, dengan media pembelajaran guru tidak perlu repot-repot lagi menulis di papan tulis, atau membawa media lain kurang menarik perhatian siswa, hal ini seperti dikemukakan oleh Juliarni, S.Pd (wawancara, tanggal 10 Nopember 2019 ) mengatakan: Walaupun saya baru memanfaatkan media pembelajaran untuk menayangkan teks dan gambar, tetapi pada prinsipnya saya merasa sangat terbantu, dan siswapun lebih tertarik, daripada menggunakan media lainnya, selain repot, juga hasilnya tidak maksimal.

Dalam proses pembelajaran penggunaan media sangat membantu poroses belajar mengajar. Berdasarkan hasil observasi atau pengamatan di kelas III A SD Negeri 009 Kepenuhan. Tema yang diajarkan pada pembelajaran itu tema 1 pertumbuhan dan perkembangan mkhluk hidup. Guru sudah menyiapkan media pembelajaran tentang makluk hidup. Media yang ditampilkan gambar-gambar pertumuhan mahluk hidup dengan infokus. Setelah penyampaian materi pertumbuhan dan perkembangan makhluk hidup, guru meminta siswa mengamati media pembelajaran yang ditayangkan dengan infokus.

Berbagai hambatan dalam pemanfatan media pembelajaran pada pembelajaran tematik terpadu kelas III Sekolah Dasar Negeri 009 Kepenuhan yang pertama adalah permasalahan kurang kesiapan guru dalam menggunakan media yang telah tersedia, guru dalam proses belajar menagajarnya banyak yang belum memanfaatkan media pembelajaran

Media pembelajaran sebagai sarana interaktif merupakan salah satu bentuk pembelajaran yang dilandasi oleh Hukum Akibat. Dalam Hukum Akibat asumsi utama yang diyakini ialah tingkah laku yang diikuti oleh rasa senang. Berdasarkan Hukum Akibat ini muncullah Teori S-R (yang meliputi stimulus, respons). Pembelajaran dengan teori ini dilakukan dengan cara siswa diberi media yang menarik sebagai stimulus dalam proses pembelajaran dan siswa memberikan jawaban (respons) dari pertanyaan yang diberikan. Dengan mengunakan media pembelajarn ternyata banyak keuntungan yang diperoleh antara lain:

(1) Media pembelajaran bila dirancang dengan baik, merupakan media pembelajaran yang efektif, dapat memudahkan dan meningkatkan kualitas pembelajaran,

(2) Meningkatkan motivasi belajar siswa,

(3)Mendukung pembelajaran individual sesuai kemampuan siswa, 
342 Pemanfaatan media pembelajaran pada pembelajaran tematik terpadu di sekolah dasar-Rejeki, M. Fachri Adnan, Pariang Sonang Siregar

(4) Dapat digunakan sebagai penyampaian pesan langsung,

\section{SIMPULAN}

Pemanfaatan media pembelajaran pada pembelajaran Tematik Terpadu pada kelas III SD Negeri 009 Kepenuhan Kabupaten Rokan Hulu Riau bila dirancang dengan baik merupakan media pembelajaran yang efektif, dapat memudahkan dan meningkatkan kualitas pembelajaran, meningkatkan motivasi belajar siswa, mendukung pembelajaran individual sesuai kemampuan siswa, dan dapat digunakan sebagai penyampaian pesan langsung. Kegunaan dan peran media pembelajaran dalam pembelajaran tematik Terpadu pada kelas III SD Negeri 009 Kepenuhan Kabupaten Rokan Hulu Riau adalah memperjelas penyajian pesan agar tidak terlalu bersifat verbalistis, mengatasi keterbatasan ruang, waktu dan daya indera. Faktor pendukung media pembelajaran pada pembelajaran tematik terpadu keals III SD Negeri 009 Kepenuhan Kabupaten Rokan Hulu adalah media pembelajaran sudah banyak di sediakan oleh sekolah dan siswa. Dengan adanya media pembelajaran siswa sangat tertarik untuk belajar, dengan kehadiran media membuat siswa lebih termotivasi untuk belajar karena siswa tidak menerawang dalam belajar. Faktor penghambat media pembelajaran pada pembelajaran tematik terpadu keals III SD Negeri 009 Kepenuhan Kabupaten Rokan Hulu adalah kurang kesiapan guru dalam menggunakan media yang telah tersedia, guru dalam proses belajar menagajarnya banyak yang belum memanfaatkan media pembelajaran, dan sumber daya manusia, guru sebagai operator harus mampu mengoperasikan leptop dan infokus dan menyusun pembelajaran yang akan disamapikan kepada siswa, keahlian guru dalam menyusun tampilan dalam pembelajaran dengan media pembelajaran sangat diperlukan

\section{DAFTAR PUSTAKA}

Adam. Steffi dan Muhammad Taufik Syastra. (2015). Pemanfaatan Media Pembelajaran Berbasis Teknologi Informasi Bagi Siswa Kelas X Sma Ananda Batam. Dalam CBIS Journal, Volume 3 No 2: 79

Arsyad,Azhar. 2019. Media Pembelajaran. Jakarta: PT. Raja Grafindo Persada.

Arief S Sadiman, dkk. 2007. Media Pendidikan. Jakarta: PT. Raja Grafindo Persada.

Budi. 2006. Belajar dan Pembelajaran. Jakarta: PT Rineka Cipta.

Heinich R., Molenda M., \& Russel, J.D. 2005. Intructional Media and The New echnologies for learning. New York : Prentice Hall Inc Company.

H.B. Sutopo. 2002. Pengantar Penelitian Kualitatif. Surakarta : Universitas Sebelas Maret Press.

Kemendikbud. 2013. Kerangka Dasar Kurikulum

2013. Kementerian Pendidikan dan Kebudayaan Direktorat Jenderal Pendidikan Dasar . Jakarta.

Mahnun.Nunu.(2012). Media Pembelajaran (Kajian terhadap Langkah-langkah PemilihanMedia dan Implementasinya dalam Pembelajaran). Dalam Jurnal Pemikiran Islam; Vol. 37, No. 1:

Purnomo, Joni, dkk. (2014). Penggunaan Media Audio-Visual Pada Mata Pelajaran Ilmu Pengetahuan Alam Di Sekolah Menengah Pertama Negeri1 Pacitan. Dalam Jurnal Teknologi Pendidikan dan Pembelajaran Vol.2, No.2: 127 Rahmayanti. (2015). 
343 Pemanfaatan media pembelajaran pada pembelajaran tematik terpadu di sekolah dasar-Rejeki, M. Fachri Adnan, Pariang Sonang Siregar

Rusman.2015.Pembelajaran Tematik Terpadu

Teori, Praktik dan Penilaian. Jakarta:

Rajawali Pers.

Rudi Susilana.Cepi Riyana,.2008.Media

Pembelajaran. Bandung :CV Wacana Prima

Sugiyono. 2017. Metode Penelitian Kualitatif.

Bandung : Alfabeta.

Suryosubroto. 2009. Proses Belajar Mengajar di Sekolah. Jakarta: Rhineka Cipta.

Suwardi., W. Anitah, S., Akhyar, M. \& Asrowi. 2017. "The Relevance Of Pictures As Media

In Thematik Learning Book With Pluralism Values In ndonesia”. International Journal of Law, Government and Communication, Volume 2 No 6, hal 1- 6. 